\title{
Current Prescribing Pattern of Antihypertensive Drugs in Preeclampsia
}

Sujit Kumar Sarker *1, Kumar Ganesan ${ }^{1}$, Ratna Paul ${ }^{2}$.

${ }^{* 1}$ Faculty of M edicine, International M edical School, M anagement \& Science University, Shah Alam, Selangor, Malaysia.

${ }^{2}$ M ohammadpur Fertility Services \& Training Centre, M ohammadpur, Dhaka, Bangladesh.

\section{ABSTRACT}

Introduction: Preeclampsia is a medical disorder encountered during pregnancy. It is a multisystem disorder characterized by new onset of hypertension presenting after 20 weeks of gestation with clinically relevant proteinuria. Failure to control blood pressure can affect both mother and fetus health.

Methods: The present study was evaluated and collected the data from Pubmed and Google Scholar databases since 2010 to 2014 and summarized current pattern of antihypertensive drugs used in preeclampsia.

Results: Among the antihypertensive drugs most commonly preferred drugs in mild to moderate hypertension by clinicians are alpha methyldopa, labetalol and nifedipine.

Conclusion: The pattern of antihypertensive drugs for treatment of preeclampsia remain same for many years due to limited clinical trials of alternative drugs.

KEY WORDS: Preeclampsia, Antihypertensive, Pregnancy, Prescribing pattern.

Address for correspondence: Sujit Kumar Sarker, Faculty of M edicine, International M edical School, Management \& Science University, Shah Alam, Selangor, Malaysia. M obile: +60142139129 ,

E-Mail: sujit_swapna@yahoo.com; ssswapnasujit3@gmail.com

\begin{tabular}{|c|c|}
\hline \multicolumn{2}{|r|}{ Online Access and Article Informtaion } \\
\hline $\begin{array}{l}\text { Quick Response code } \\
\text { (a) }\end{array}$ & $\begin{array}{l}\text { International Journal of Integrative Medical Sciences } \\
\text { www.imedsciences.com }\end{array}$ \\
\hline Dol: 10.16965 /jims.2015.114 & $\begin{array}{l}\text { Received: 15-04-2015 } \\
\text { Reviewed: 15-04-2015 ine } \quad \text { Accepted: 27-04-2015 }\end{array}$ \\
\hline Source of Funding: Self & Conflicts of inte \\
\hline
\end{tabular}

\section{INTRODUCTION}

Hypertension in pregnancy remains a significant public health problem [1], which complicate $6-8 \%$ of pregnancies and cause significant maternal and fetal morbidity and mortality [2]. This rate will probably rise in the years to come due to the notable tendency among women to delay the decision to become pregnant, occurrence of arterial hypertension increase with age, as well as due to the growing problem of obesity resulting from inappropriate dietary habits and lack of regular everyday physical activity [3]. Pre-eclampsia is more common among women likely to have a large placenta (such as those with multiple pregnancy) and among women with medical conditions associaed with microvascular disease (such as diabetes, hypertension, and collagen vascular disease) and may result from deficient placental implantation during the first-half of pregnancy [4]. Preeclampsia was formerly defined as a multisystem disorder characterized by new onset of hypertension i.e. systolic blood pressure (SBP) $\geq 140 \mathrm{mmHg}$ and/or diastolic blood pressure $(\mathrm{DBP}) \geq 90 \mathrm{mmHg}$ ) and proteinuria (> $300 \mathrm{mg} / 24 \mathrm{~h}$ ) arising after 20 weeks of gestation in a previously normotensive woman. Recently, the American College of Obstetricians and Gynecologists has stated that proteinuria is no longer required for the diagnosis of preeclampsia [5]. 
Gestational hypertension is a new hypertension presenting after 20 weeks gestation without clinically relevant proteinuria. Severe pre-eclampsia is the pre-eclampsia with severe hypertension or with symptoms, biochemical abnormalities, or hematological impairment (or any combination thereof). Chronic hypertension is a hypertension that present at booking visit or before 20 weeks gestation, or being treated at time of referral to maternity services; can be primary or secondary in etiology [6].

Few antihypertensive drugs are used for the treatment of preeclampsia to control blood pressure, as there is little to guide the choice of agent. The reason behind this is less amount of scientific research during pregnancy. Based on the above findings, the present study was to determine prevalence of antihypertensive drugs used in preeclampsia.

\section{METHODOLOGY}

For the present study, the information and data were collected from Pubmed and Google scholar databases, which has been published in English since 2010 to 2014 and identified the drugs used for preeclampsia.

\section{RESULTS}

Table 1: Summary of recommended antihypertensive drugs for the treatment of preeclampsia.

\begin{tabular}{|c|c|c|c|c|}
\hline Studies & $\begin{array}{l}\text { Centrally acting } \\
\text { sympathoplegic }\end{array}$ & $\begin{array}{l}\text { Calcium Channel } \\
\text { blocker }\end{array}$ & $\begin{array}{l}\begin{array}{l}\beta \text {-adrenoceptor } \\
\text { blocker }\end{array}\end{array}$ & Combinations/Others \\
\hline Abalos E et al.,2014 [9] & Alpha Methyldopa & Wointe & & $\begin{array}{l}\text { Combination of Calcium } \\
\text { channel blocker and } \\
\beta \text {-adrenoceptor blocker }\end{array}$ \\
\hline Firoz Tet al., 2014 [12] & Alpha M ethyldopa & Nifedipine & Labetalol & Hydralazine \\
\hline Kumar S et al., 2014 [10] & Alpha M ethyldopa & $\begin{array}{l}\text { Nifedipine, } \\
\text { Amlodipine }\end{array}$ & $\begin{array}{l}\text { Labetalol, } \\
\text { Atenolol }\end{array}$ & \\
\hline Arulkumaran N, Lightstone L, 2013 [20] & Alpha M ethyldopa & Nifedipine & Labetalol & \\
\hline Kattah AG, Garovic VD, 2013 [2] & Alpha M ethyldopa & Nifedipine & Labetalol & Thiazide, Hydralazine \\
\hline Lalani S, Firoz T, Magee LA et al., 2013 [11] & Alpha M ethyldopa & Nifedipine & $\begin{array}{l}\text { Propranolol, } \\
\text { Atenolol }\end{array}$ & \\
\hline Xie RH, Guo Y, Krewski D et al.,2013 [21] & Alpha M ethyldopa & & Labetalol & \\
\hline Carles G, Helou J, Dallah F et al., 2012 [14] & & & & Urapidil \\
\hline Liu QQ, Yu YH, Gong SP, et al., 2012 [22] & & Nifedipine & & \\
\hline Szczepaniak-Chicheł L, Tykarski A, 2012 [3] & Alpha M ethyldopa & $\begin{array}{l}\text { Nifedipine, } \\
\text { Verapamil }\end{array}$ & $\begin{array}{l}\text { Labetalol, } \\
\text { Metoprolol }\end{array}$ & \\
\hline Vest AR, Cho LS, 2012 [13] & Alpha M ethyldopa & Nifedipine & Labetalol & Hydralazine \\
\hline Brown CM, Garovic VD, 2011 [7] & Alpha M ethyldopa & Nifedipine & Labetalol & $\begin{array}{c}\text { Oxprenolol, Clonidine, } \\
\text { Hydralazine }\end{array}$ \\
\hline $\begin{array}{l}\text { Magee LA, Abalos E, von Dadelszen P et al., } \\
2011[8]\end{array}$ & Alpha M ethyldopa & Nifedipine & Labetalol & Hydralazine \\
\hline Podymow T, August P, 2011 [23] & Alpha M ethyldopa & Nifedipine & Labetalol & \\
\hline Solomon CG, Seely EW, 2011 [24] & Alpha M ethyldopa & & Labetalol & \\
\hline Buch J, 2010 [15] & & & & Urapidil \\
\hline Fabry IG, Richart T, Chengz X et al., 2010 [25] & Alpha Methyldopa & Nifedipine & & \\
\hline
\end{tabular}


Abalos E et al.,2014 [9] suggested combination of calcium channel blocker and $\beta$-adrenoceptor blocker along with alpha methyldopa. Among calcium channel blocker all studies suggested nifedipine, Kumar S et al., 2014 [10] suggested nifedipine and amlodipine and SzczepaniakChiche L, Tykarski A, 2012 [3] suggested nifedipine and verapamil. Regarding $\beta$ adrenoceptor blocker all studies suggested labetalol, Kumar S et al., 2014 [10] suggested labetalol and atenolol, Lalani S, Firoz T, Magee LA et al., 2013 [11] suggested propranolol and atenolol and Szczepaniak-Chiche L, Tykarski A, 2012 [3] suggested labetalol and metoprolol. Other than these, hydralazine (vasodilator) is suggested by Firoz T et al., 2014 [12], Kattah AG, Garovic VD, 2013 [2], Vest AR, Cho LS, 2012 [13], Brown CM , Garovic VD, 2011 [7] \& Magee LA, Abalos E, von Dadelszen P et al., 2011 [8], urapidil ( $\alpha$-adrenoceptor antagonist) is suggested by Carles G, Helou J, 2012 [14] \& Buch J, 2010 [15]. Table I summarizes the recommended antihypertensive drugs for the treatment of preeclampsia that are most widely accepted and practiced.

\section{DISCUSSION}

Pre-eclampsia is a major cause of maternal mortality and morbidity, preterm birth, perinatal death, and intrauterine growth restriction. Unfortunately, the pathophysiology of this multisystem disorder, characterized by abnormal vascular response to placentation, is still unclear [16]

Antihypertensive medications used to control hypertension in early pregnancy can alter placental and circulating cytokines. The interaction between trophoblasts and maternal endothelium is important for placental vascular modeling. M ethyldopa, labetalol, hydralazine, and clonidine increased trophoblast integration into TNF- $\alpha$-preincubated endothelial cellular networks. Methyldopa increases vascular endothelial growth factor (VEGF) and decreases placental growth factor [17]. There is also a reduction in the overall risk of developing proteinuria/pre-eclampsia when beta blockers and calcium channel blockers considered together are compared with methyldopa [9].
Up regulation of inducible nitric oxide synthase (iNOS) has been reported in both experimental and clinical hypertension. Inducible nitric oxide synthase inhibitors (iNOS) could be clinically useful in the therapy of preeclampsia, especially in particular groups of patients genetically more prone to express higher levels of iNOS [18]. Aminopeptidase A (APA) acts as an antihypertensive agent in the pregnant spontaneously hypertensive rat by degrading vasoactive peptides and as a result returns the animal to a normotensive state [19].

It is important to note that mild to moderate hypertension requires therapy in pregnancy, although somewhat different among various groups and professional societies. One important reason behind this difference is that, there are few well-designed clinical trials establishing the benefit of treating mild to moderate hypertension during pregnancy. The antihypertensive choice for preeclampsia has been limited to those that have relatively less adverse effects and have a long history of clinical use by obstetricians and gynecologists.

\section{CONCLUSION}

Current antihypertensive recommendations for the treatment of preeclampsia remained same for many years. It is due to lack of studies in a critical period of life which can affect both mother and fetus health. Further studies are required for effective control blood pressure during pregnancy.

\section{REFERENCES}

[1]. Easterling TR. Pharmacological management of hypertension in pregnancy. Semin Perinatol 2014;38(8):487-95.

[2]. Kattah AG, Garovic VD. The management of hypertension in pregnancy. Adv Chronic Kidney Dis 2013;20(3):229-39.

[3]. Szczepaniak-Chiche L, Tykarski A. Treatment of arterial hypertension in pregnancy in relation to current guidelines of the Polish Society of Arterial Hypertension from 2011. Ginekol Pol. 2012;83(10):778-83.

[4]. Duley L. Pre-eclampsia, eclampsia, and hypertension. BMJ Clin Evid. 2011, pii: 1402.

[5]. Lambert G, Brichant JF, Hartstein G, Bonhomme V, Dewandre PY. Preeclampsia: an update. Acta Anaesthesiol Belg 2014;65(4):137-49. 
[6]. Visintin C, M ugglestone M A, Almerie M Q, Nherera $L M$, James $D$, Walkinshaw $S$ : $M$ anagement of hypertensive disorders during pregnancy: summary of NICE guidance. BMJ. 2010, 341: C2207.

[7]. Brown CM, Garovic VD. Mechanisms and management of hypertension in pregnant women. Curr Hypertens Rep. 2011;13(5):338-46.

[8]. Magee LA, Abalos E, von Dadelszen P, Sibai B, Easterling T, Walkinshaw $S$. How to manage hypertension in pregnancy effectively. $\mathrm{Br} \mathrm{J}$ Clin Pharmacol. 2011;72(3):394-401.

[9]. Abalos E, Duley L, Steyn DW. Antihypertensive drug therapy for mild to moderate hypertension during pregnancy. Cochrane Database Syst Rev. 2014;2:CD002252.

[10]. Kumar S, Bansal D, Hota D, Jain M , Singh P, Pandey $\mathrm{BL}$. Assessment of clinical outcomes and prescribing behavior among inpatients with severe preeclampsia and eclampsia: an Indian experience. Indian J Pharmacol. 2014;46(1):18-23.

[11]. Lalani S, Firoz T, Magee LA, Sawchuck D, Payne B, Gordon $R$, Vidler $M$, von Dadelszen $P$. Pharmacotherapy for preeclampsia in low and middle income countries: an analysis of essential medicines lists. J Obstet Gynaecol Can. 2013;35(3):215-23.

[12]. Firoz T, M agee LA, M acDonell K, Payne BA, Gordon $R$, Vidler $M$, von Dadelszen P. Oral antihypertensive therapy for severe hypertension in pregnancy and postpartum: a systematic review. BJOG.2014;121(10):1210-8.

[13]. Vest AR, Cho LS. Hypertension in pregnancy. Cardiol Clin. 2012;30(3):407-23.

[14]. Carles G, Helou J, Dallah F, Ibrahim N, Alassas N, Youssef $M$. Use of injectable urapidil in pregnancyinduced hypertension and preeclampsia. J Gynecol Obstet Biol Reprod (Paris). 2012;41(7):645-9.

[15]. Buch J. Urapidil, a dual-acting antihypertensive agent: Current usage considerations. Adv Ther. 2010;27(7):426-43.

[16]. Jennifer Uzan, M arie Carbonnel, Olivier Piconne, Roland Asmar and Jean-Marc Ayoubi. Preeclampsia: pathophysiology, diagnosis, and management. Vasc Health Risk M anag. 2011;7:467474.
[17].Xu B, Charlton F, Makris A, Hennessy A. Antihypertensive drugs methyldopa, labetalol, hydralazine, and clonidine improve trophoblast interaction with endothelial cellular networks in vitro. J Hypertens. 2014;32(5):1075-83.

[18]. Amaral LM, Pinheiro LC, Guimaraes DA, Palei AC, Sertório JT, Portella RL, Tanus-Santos JE. Antihypertensive effects of inducible nitric oxide synthase inhibition in experimental pre-eclampsia. J Cell M ol Med. 2013;17(10):1300-7.

[19]. M izutani S, Wright J, Kobayashi H. A new approach regarding the treatment of preeclampsia and preterm labor. Life Sci. 2011;88(1-2):17-23.

[20]. Arulkumaran N, Lightstone L. Severe pre-eclampsia and hypertensive crises. Best Pract Res Clin Obstet Gynaecol. 2013;27(6):877-84.

[21]. Xie RH, Guo Y, Krewski D, M attison D, Nerenberg K, Walker M C, Wen SW. Trends in using beta-blockers and methyldopa for hypertensive disorders during pregnancy in a Canadian population. Eur J Obstet Gynecol Reprod Biol. 2013;171(2):281-5.

[22]. Liu QQ, Yu YH, Gong SP, Huang LP. Clinical efficacy and perinatal outcome of nifedipine for severe preeclampsia: meta-analysis. Zhonghua Fu Chan Ke Za Zhi. 2012;47(8):592-7.

[23]. Podymow T, August P. Antihypertensive drugs in pregnancy. Semin Nephrol. 2011;31(1):70-85.

[24]. Solomon CG, Seely EW. Hypertension in pregnancy. Endocrinol M etab Clin North Am. 2011;40(4):84763.

[25]. Fabry IG, Richart T, Chengz X, Van Bortel LM, Staessen JA. Diagnosis and treatment of hypertensive disorders during pregnancy. Acta Clin Belg. 2010;65(4):229-36.

[26]. CW G Redman: Hypertension in pregnancy. the NICE guidelines. Heart 2011;97:1967-1969.

[27]. Tessa E. R. Gillon, Anouk Pels, Peter von Dadelszen, Karen MacDonell, and Laura A. Magee. Hypertensive Disorders of Pregnancy: A Systematic Review of International Clinical Practice Guidelines. PLoS One. 2014;9(12):e113715.

[28]. Tallarek AC, Stepan H. Preeclampsia and HELLP syndrome as an obstetric emergency. Med Klin Intensivmed Notfmed. 2012;107(2):96-100.

\section{How to cite this article:}

Sujit Kumar Sarker, Kumar Ganesan, Ratna Paul. Current Prescribing Pattern of Antihypertensive Drugs in Preeclampsia. Int J Intg Med Sci 2015;2(4):110-113. DOI:10.16965/ijims.2015.114 